

\title{
TOURISM-LED GROWTH HYPOTHESIS AND ECONOMIC GROWTH IN KENYA
}

\author{
$1^{*}$ Justin Yano \\ ${ }^{1}$ Post Graduate Student: Jomo Kenyatta University of Agriculture and Technology \\ *Corresponding Author's E-mail: yanojustin@gmail.com \\ ${ }^{2}$ Dr. Joshua Matanda \\ ${ }^{1}$ Lecturer: Jomo Kenyatta University of Agriculture and Technology
}

\begin{abstract}
Purpose: The purpose of this study was to analyze tourism-led growth hypothesis in Kenya's economy.

Materials and Methods: The descriptive research design was adopted. This study targeted international tourism receipts, employment, economies of scale and capital investments in tourism related economic activities that included hotels and food service activities, wholesale and retail trade, transport and information communication and travel agencies, entertainment and recreation in the period 1980 to 2019.The study used purposive sampling. a sample size of data for 40 years from 1980 to 2019 was used. The data were collected from KNBS, the World Bank and WTTC using a secondary data collection sheet. Using real GDP per capita as the dependent variable and international tourism receipts, tourism related employment, economies of scale and capital investments as the independent variables, the study used regression and vector error correction (VEC) to carry out the analysis. The analysis was systematic and begins with diagnostic tests that included Breusch-Godfrey Serial Correlation LM test, Breusch-PaganGodfrey test for homoscedasticity, Jarque-Bera normality test, VIF multi-collinearity test, Augmented Dickey Fuller unit root test and Johansen Co-integration test and finally the regression and the vector error correction analysis. Data analysis was done using E-views software.
\end{abstract}

Results: The study results showed that international tourism receipts, tourism related employment and economies of scale positively influence real GDP per capita in both short run and long run equilibrium. Capital investments negatively affected real GDP per capita in the long run but had a positive effect in the short run equilibrium. Granger causality test presented a bidirectional causality between international tourism receipts, tourism related employment, economies of scale and capital investments and real GDP per capita.

Unique contribution to theory, practice and policy: The country should enact policies that promote tourism related activities because the benefits derived from tourist expenditures positively influence the growth of the economy. Institutions such as Brand Kenya, Tourism Promotion Council, the Ministry of Tourism and recruitment of international tourism ambassadors should be strengthened to ensure more foreign tourists are attracted into the country.

Key words: Tourism-Led Growth, Economic Growth 


\subsection{INTRODUCTION}

Tourism industry is one of the leading sectors for economic development and job creation throughout the world, and it is one of the biggest and fastest-growing industries with widely acknowledged significant contribution to global economic development (WTTC, 2017). Tourism activity promotes growth and development of countries, especially international tourism that brings in foreign currencies that are used for the financing of capital assets, which allow improvements to be made in the production of goods and services (WTTC, 2017).

To estimate the contribution in economic development of a country, tourism industry, like any other field of interest, requires identification of direct and measurable products specific to it. The complexity in economics of interactions of tourism product lines and their markets has, however, not been easy to understand, making unclear its role in the economy. While some economists support the argument that tourism output refers to the concept of an intangible service that the tourist enjoys while in holidays, supplied by system of enterprises, others view tourism output as a complex mixture of goods and services, Gilbert (1990). The economics of tourism can be understood as an applied discipline positioned within the broad borders of the economic science, Candela and Figini (2009). The economic role of tourism has mainly been of an economic catalyst, causing growth of other sectors in the economy through backward and forward linkages. Increasing tourism flows can bring many positive economic benefits to the supplying country through generation of income and increasing employment levels, generating revenues and foreign exchange earnings. The economic linkages created by tourism industry stimulate development of other domestic industries in the host country through linkages

An important characteristic of tourism is its direct effect in increasing employment opportunities. Through tourism, additional jobs, ranging from low-paying entry-level to high-paying professional positions in management and technical fields can be created. To meet this travelerrelated demand for goods and services, many producer industries in the host country are established. Hotels will be built, farmers produce more, promotion of cultural activities, establishment of tours and travel activities, and government investment in infrastructure such as roads, airports and railways. With these forward and backward linkages, tourism activities generate many job opportunities, and many countries are interested in their development, UNWTO and ILO (2014). The United Nations World Tourism Organization (UNWTO) estimated tourism's total contribution to global employment in 2013 between 6 and 7 per cent of the overall number of jobs in the world. These jobs result in improved households' final consumption expenditures, leading to improved standards of living.

Another input of tourism in the economy is its outstanding impact to growth of international trade in services. In 2013, the international income through tourism represented $30 \%$ of global export services, and 6\% of the total global exports of goods and services, UNWTO (2015). Expenditures incurred by international tourists are considered products in international trade; as exports in the host country and as imports in the country of origin of the visitor. In Balance of Payments accounts, receipts from inbound tourists are treated under services as credits while those from outbound visitors are treated as debits. In its 2014 report, UNWTO estimates international tourism to have generated US\$ 1,245 billion as credits in tourism receipts and US\$ 221 billion in passenger transport, resulting to total tourism export earnings of up to a daily 
International Journal of Economics

ISSN 2518-8437 (Online)

Vol.6, Issue 1, No.1.pp 1 - 22, 2021

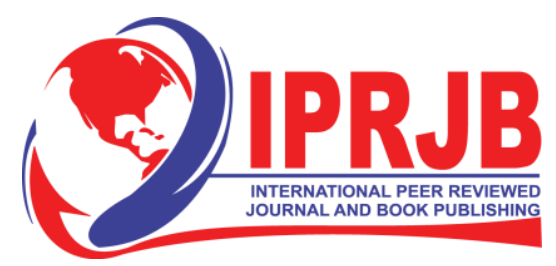

www.iprjb.org

average of US\$ 4 billion. This meant a $6 \%$ of overall exports of goods and services and $30 \%$ of the world's exports of services.

Besides promotion of tourism products, the tourism related infrastructure also drive development in the country by stimulating development of other sectors of the economy such as transportation, construction, agriculture, and manufacturing UNCTAD (2010). The development of tourism destination areas, most of which are located in the rural areas, has also brought with it social and public benefits to the local communities. Tourism expansion means availability of public utilities such as water and sewer services, electricity, parking, modern public toilets, garbage collection and disposal, and landscaping, Kreag (2001). These amenities are beneficial to both the tourists and the community.

In World Travel and Tourism Council (WTTC) 2017 report, Travel and Tourism directly contributed US\$2.3 trillion and 109 million jobs worldwide. Both indirect and induced impacts of the sector accounted for US\$7.6 trillion to the global economy and supported 292 million jobs in 2016, representing $10.2 \%$ of the world's GDP, and approximately 1 in 10 of all jobs, WTTC (2017). In Africa, tourism sector development has helped in alleviating economic problems such as high rates of unemployment, limited foreign reserves and unfavorable trade balances that have characterized most economies in the region. In Africa, travel and tourism activities directly contributed 3.1\% (66.4 billion US dollars) of the region's GDP in 2016, according to World Travel and Tourism Council 2017 report. In total, tourism and tourism related industries contributed 7.8\%, equivalent of US\$165.6 billion to Africa's Gross Domestic Product in 2016. During this period, $2.6 \%$ (8.4 Million jobs) of total jobs created in Africa were mostly noticeable in travel and tourism sector. The World Travel and Tourism Council estimated the travel and tourism activities to have attracted US\$28.5billion worth of investment in Africa alone in 2016. In Kenya, Travel and Tourism recorded $3.7 \%$ and $9.8 \%$ as direct and indirect contribution to GDP respectively in 2016, WTTC (2017), illustrating tourism as a driving force in Kenya's economy. This is an indication that development of tourism sector is essential in alleviating high rates of unemployment, limited foreign exchange and unfavorable trade balances that have characterized most of Africa's economies.

In Kenya, due to its forward and backward linkages to other economic sectors such as farming, processing, financial activities, wildlife, arts, entertainment and handicrafts, tourism activities have a pronounced potential to create employment and wealth, G.O.K (2007). The mainstay of Kenya's tourism activities are the wildlife safaris, and most parks in the country such as Tsavo National Park and Maasai Mara National Park are among the best places to see lions, elephants and leopards. Tourists also come to Maasai Mara in Kenya to experience the famous wildebeest migration. According to Kenya's development blueprint, Kenya Vision 2030 (2007), tourism and related activities are reported to account nearly 10 per cent of Kenya's economic growth and about 9 per cent of total employment in the formal sector. The sector has kept a faster growth and has proved as one of the reliable sectors of the economy in boosting foreign exchange earnings for the country, generating an estimated US\$800 million in 2006 according to the blue print. During the 2016 UNCTAD meeting in Nairobi, Kenya's Cabinet Secretary in charge of tourism recognized tourism as "a key instrument for sustainable development as it can stimulate economic growth, create jobs, attract investment, foster entrepreneurship...”. 
International Journal of Economics

ISSN 2518-8437 (Online)

Vol.6, Issue 1, No.1.pp 1 - 22, 2021

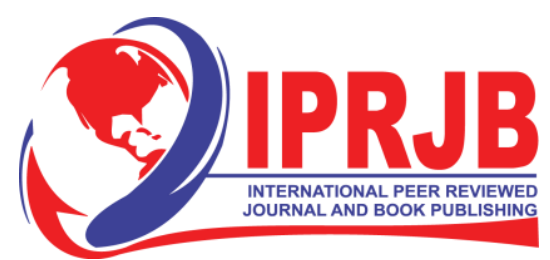

WWW.iprjb.org

Figure 1 shows the trend of international visitor arrivals in Kenya for eighteen years from 2000 to 2017.

\section{INBOUND TOURISTS}

$\multimap$ Inbound tourists

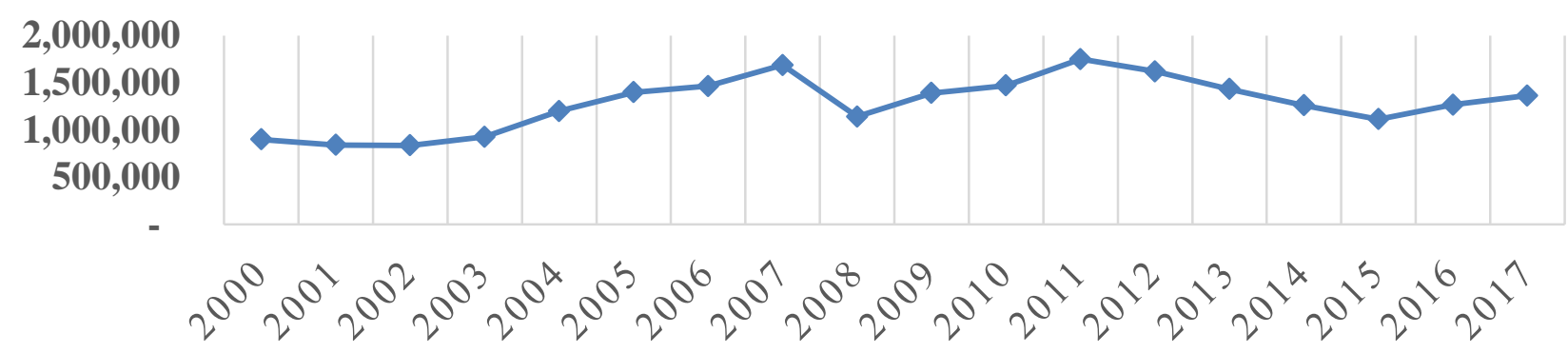

Figure 1: International visitor Arrivals in Kenya, 2000-2017

As shown in Figure 1, the number of international visitor arrivals visiting Kenya increased steady from 2002 except in 2008 and 2015. It can be explained that the drop in tourist arrivals is attributed to the post-election violence and terrorist attacks that rocked the country in 2008 and 2015 respectively. In Table 1, the contribution of international tourism to Kenya's international trade is illustrated. The table shows the levels of total export and import trade, tourism receipts and expenditures and their shares in total exports and imports respectively. 
International Journal of Economics

ISSN 2518-8437 (Online)

Vol.6, Issue 1, No.1. pp 1 - 22, 2021

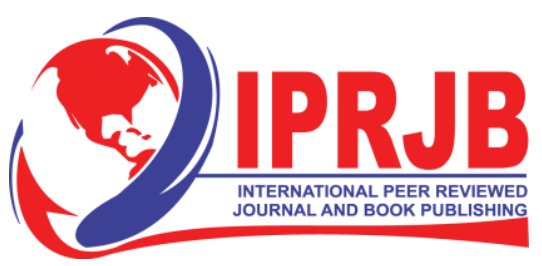

WwW.iprjb.org

\$able 1: International Trade and International Tourism in Kenya, 2000-2015

\begin{tabular}{|c|c|c|c|c|c|c|}
\hline \begin{tabular}{|l|} 
Char \\
Years
\end{tabular} & $\begin{array}{l}\text { rea prts, } \\
\text { (Rssh } \\
\text { million) }\end{array}$ & $\begin{array}{l}\text { Intemational } \\
\text { tourism receipts } \\
\text { (KSh million) }\end{array}$ & $\begin{array}{l}\text { Tourism } \\
\text { receipts } \\
\text { Exports } \\
(\%)\end{array}$ & $\begin{array}{l}\text { Imports, } \\
\text { KSh million }\end{array}$ & $\begin{array}{l}\text { Intemational } \\
\text { tourism } \\
\text { expenditures } \\
\text { (KSh million) } \\
\end{array}$ & $\begin{array}{l}\text { Tourism } \\
\text { expenditures } \\
\text { Imports (\%) }\end{array}$ \\
\hline 2000 & 367,080 & 38,088 & 10.4 & 307,012 & 11,883 & 3.9 \\
\hline 2001 & 380,322 & 42,110 & 11.1 & 336,829 & 14,377 & 4.3 \\
\hline 2002 & 407,382 & 40,388 & 9.9 & 313,456 & 9,920 & 3.2 \\
\hline 2003 & 436,763 & 47,001 & 10.8 & 340,049 & 9,643 & 2.8 \\
\hline 2004 & 491,773 & 63,259 & 12.9 & 418,830 & 8,551 & 2.0 \\
\hline 2005 & 537,900 & 73,207 & 13.6 & 509,234 & 9,368 & 1.8 \\
\hline 2006 & 556,944 & 85,151 & 15.3 & 600,537 & 12,834 & 2.1 \\
\hline 2007 & 591,238 & 101,919 & 17.2 & 687,911 & 17,839 & 2.6 \\
\hline 2008 & 605,261 & 96,722 & 16.0 & 866,700 & 18,403 & 2.1 \\
\hline 2009 & 573,672 & 87,007 & 15.2 & 882,904 & 17,572 & 2.0 \\
\hline 2010 & 623,836 & 128,358 & 20.6 & $1,063,942$ & 16,797 & 1.6 \\
\hline 2011 & 681,289 & 163,767 & 24.0 & $1,446,502$ & 17,496 & 1.2 \\
\hline 2012 & 727,502 & 169,395 & 23.3 & $1,514,394$ & 14,708 & 1.0 \\
\hline 2013 & 711,768 & 157,519 & 22.1 & $1,575,731$ & 20,067 & 1.3 \\
\hline 2014 & 753,318 & 153,424 & 20.4 & $1,782,945$ & 18,112 & 1.0 \\
\hline 2015 & 800,053 & 156,694 & 19.6 & $1,734,755$ & 21,305 & 1.2 \\
\hline Mean & 577,881 & 100,251 & 16.4 & 898,858 & 14,930 & 2.1 \\
\hline
\end{tabular}

Source: World Bank

As shown in Table 1, international tourism receipts play a significant role in international trade, contributing an average of 16.4 per cent of total export trade, equivalent to KSh. 100,251million between the years 2000 and 2015. The expenditures by Kenyans in international tourism is very low, representing an average of 2.1 per cent of total import values. These statistics are indicative of the influence international tourism has on economic development in Kenya.

Figure 2 illustrates the direct contribution of tourism activities to Kenya's economy for period 2001 to 2017. 


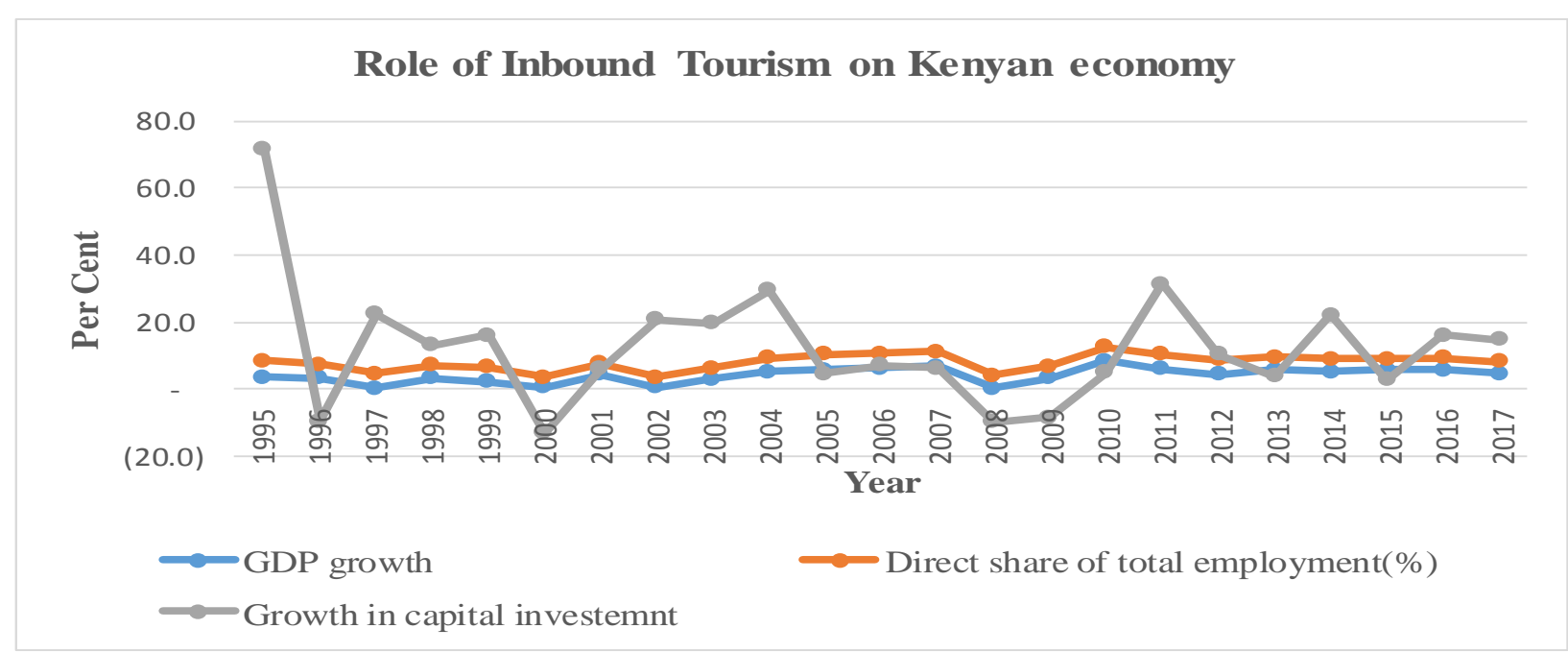

Figure 2: Economic Role of International tourism in Kenya

\section{Tourism-Led Growth Hypothesis}

Traditionally, tourism has been defined as travel of people to destinations that are away from their usual residences and the provisions of facilities created to cater for the needs arising along this travel (Mathieson \& Wall, 1982). But the United Nations World Tourism Organization (UNWTO) provides the modern definition of tourism as activities of people who travel to and stay in places away from their usual locations for a period not exceeding a year for either leisure, business or other reasons.

Such activities impact on the economic development of the destination countries. In their efforts to improve their share in international trade, many countries have had a strong deliberation on promotion of international tourism activities for economic growth. The impact of international tourism on economies of developing countries has attracted a lot of interest from both scholars and policy makers (Clancy, 1999).

The Tourism-led growth hypothesis proposes that expansion in international tourism results in economic growth. The hypothesis was first put forward and tested by Balaguer and CantavellaJordá (2002) in Spain during which they established that growth in international tourism led to economic growth in the long run. Since tourism is considered a non-traded good in international trade, the tourism-led growth hypothesis was built on the background of literature of export-led growth hypothesis and other theoretical models that treated tourism as such.

Just like the export-led growth hypothesis, tourism-led growth hypothesis posts tourism as a main determinant of overall long-run economic growth. Basically, the hypothesis focuses on tourism as a source of foreign exchange, which is revenue that can be used to purchase capital goods used in production of goods and services, thus enabling economic growth. Similarly, tourism as an export generates and/or raises the income levels of the citizens in the host countries by creating more job opportunities. Tourism improves efficiency in production of goods and services through competition among firms in the host country and from goods and services from other international tourist destinations Bhagwati and Srinivasan (2002), in addition to enabling exploitation of economies of scale in local firms (Helpman \& Krugman, 1985). 


\section{Statement of the Problem}

Tourism industry has been considered a significant sector in generation of foreign exchange earnings, creation of job opportunities, increasing investment levels, Foon and Salah (2014) and alleviating current account and balance of payment deficits through international tourism receipts, Oh, 2005; Mello-Sampayo and Souza-Vale (2010). The World Travel and Tourism Council argues that Travel \& Tourism continues to be one of the world's largest industries having contributed to the global GDP by $10.2 \%$, WTTC (2017). In Kenya, the WTTC estimated direct and indirect contribution of tourism activities to GDP in 2016 at $3.7 \%$ and $9.8 \%$ respectively. In 2016, Kenya was ranked among the leading tourist destinations in the SubSaharan region, boasting a $17.0 \%$ growth in international tourism arrivals who spent approximately US\$. 824 Million in the country (UNWTO, 2017).

These empirical reports have seen more countries increase their attention on tourism industry, with more focus on international tourism as an important potential growth sector, Brohman (1996). In Kenya, the country's development blueprint, Kenya Vision 2030, identifies forward and backward linkages of tourism industry to other economic sectors such as manufacturing, financial activities, wildlife, arts, entertainment and handicrafts as key to deliver the projected 10.0 per cent annual economic growth rate, G.O.K( 2007). In this regard, there are some studies that have attempted to explain the relationship between tourism spending and economic growth in both developed and developing economies Chou (2013). While majority of the studies have found tourism spending to cause economic growth, others such as Dwyer and Forsyth (1993) note that though tourism is seen as increasing overall economic activity, more often than not, the positive impacts on economic activity are inaccurately described since the "benefits" of tourism expansion increases relative prices of non-traded goods, Chao, Bharat, Jean-Pierre, Pasquale and Eden (2006). They further argue that increase in relative price of non-traded goods lowers the demand for capital in traded sector, resulting in de-industrialization that may lower residents' welfare and negatively impacting on economic growth. Holzner (2011) in the study titled Tourism and Economic Development: the beach disease? finds that tourism-dependent countries do face real exchange rate distortion and de-industrialization.

Lee (2008) and Holzner (2011) find that different countries show different causality directions between tourism spending and economic growth, suggesting that tourism spending-growth relationships may be country-specific. In Kenya, while studies by Obadia, Nicholas and Josephine (2012), Valle (2009) among others find a positive causality from tourism to economic growth, there still exists the argument that although the sector plays a critical role in the economy, its actual and potential contribution to development is still in doubt, with claims that its contribution to the country's economy is less than it's usually thought, (World Bank ,2017).

The major motivation of this study is to complement prior studies by analyzing tourism-led growth hypothesis in Kenyan economy. The study uses advanced econometric methodologies to analyze data to generate information that will account for international tourism activities, thereby contributing in closing the information gap on the role of tourism sector in Kenyan economy. 
International Journal of Economics

ISSN 2518-8437 (Online)

Vol.6, Issue 1, No.1. pp 1 - 22, 2021

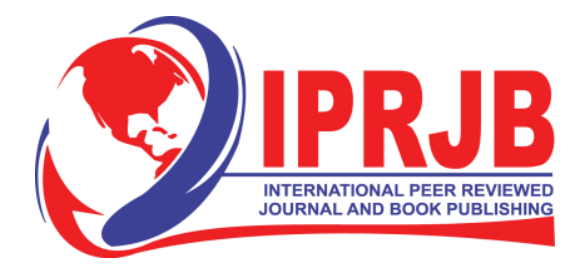

www.iprjb.org

\section{Tourism Receipts}

- Annual income from expenditures of international tourists.

- Number of international tourists

\section{Employment}

- Share of tourism employment

- Annual employment in tourism related industries

\section{Economies of Scale}

- Input-value added ratio

- Ratio of cost price and value added of tourism related industries

\section{Capital Investment}

- Tourism related investments

- Capital investments

\section{Independent Variables}

\section{Dependent Variable}

\section{Figure 2: Conceptual Framework}

\subsection{METHODOLOGY}

The descriptive research design was adopted. This study targeted international tourism receipts, employment, economies of scale and capital investments in tourism related economic activities that included hotels and food service activities, wholesale and retail trade, transport and information communication and travel agencies, entertainment and recreation in the period 1980 to 2019.The study used purposive sampling. a sample size of data for 40 years from 1980 to 2019 was used. The data were collected from KNBS, the World Bank and WTTC using a secondary data collection sheet. Using real GDP per capita as the dependent variable and international tourism receipts, tourism related employment, economies of scale and capital investments as the independent variables, the study used regression and vector error correction (VEC) to carry out the analysis. The analysis was systematic and begins with diagnostic tests that included Breusch-Godfrey Serial Correlation LM test, Breusch-Pagan-Godfrey test for homoscedasticity, Jarque-Bera normality test, VIF multi-collinearity test, Augmented Dickey 
International Journal of Economics

ISSN 2518-8437 (Online)

Vol.6, Issue 1, No.1. pp 1 - 22, 2021

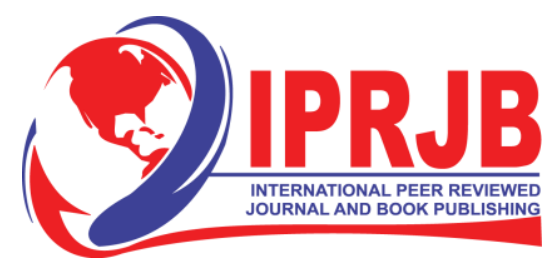

WwW.iprjb.org

Fuller unit root test and Johansen Co-integration test and finally the regression and the vector error correction analysis. Data analysis was done using E-views software.

\subsection{RESULTS}

\subsection{Descriptive Analysis}

Table 2 presents descriptive measures of the indicators used in this study. From the table, Kenya recorded a mean of KSh. 77,746 in real GDP per capita and KSh. 848 million in real receipts from international tourism between 1980 and 2019. Similarly, the country has been accumulating on average KSh. 18.7 million worth of tourism related investment while tourism related industries have recorded an average of 90.0 per cent of their gross value added as the cost of inputs over the period under study. Tourism related activities have employed on average 680 thousand people, with the highest and lowest number of jobs created over the period is 1,180 thousand and 81 thousand respectively. In the 40 years studied, Kenya registered a maximum and a minimum real GDP per capita of KSh. 106,244 and KSh. 68,468 respectively. The maximum cost price tourism related industries have recorded as percentage of their total gross value added is 100.8 .

Table 2. Descriptive Measures

\begin{tabular}{llllllll}
\hline \hline Variable & Mean & Median & Maximum & Minimum & $\begin{array}{c}\text { Std. } \\
\text { Dev. }\end{array}$ & Skewness & Kurtosis \\
\hline GDP & 77,746 & 74,578 & 106,244 & 68,468 & 9,922 & 1.5 & 4.4 \\
ITR & 848 & 881 & 1,016 & 582 & 128 & -0.6 & 2.2 \\
EMPL & 680 & 728 & 1,180 & 81 & 373 & -0.3 & 1.6 \\
IoR & 90.0 & 94.6 & 100.8 & 61.6 & 11.1 & -1.5 & 3.7 \\
GFCF & 18.7 & 20.2 & 23.6 & 12.9 & 3.0 & -0.5 & 2.1 \\
\hline \hline
\end{tabular}

As shown in Figure 4, the country has been experiencing a rising level of economic performance from 2004 to date. During this period, the government developed and implemented development plans such as the Economic Recovery Strategy for Wealth and Employment Creation between 2002 and 2007 and the Vision 2030 development plan. The liberalization of markets, removal of price controls as well as abolition of foreign exchange controls helped in positively influencing expenditures by international tourists. As indicated in the graphs, uncertainties of election outcomes negatively wedged economic activities in the country during 2002 and 2008 . The 2008 post-election violence adversely impacted on the economy in its entirety, with all the economic variables considered in this study showing a decline. The violence scared away both tourists and potential investors, resulting in decline in tourism receipts, capital investments and general economic growth. 
International Journal of Economics

ISSN 2518-8437 (Online)

Vol.6, Issue 1, No.1. pp 1 - 22, 2021

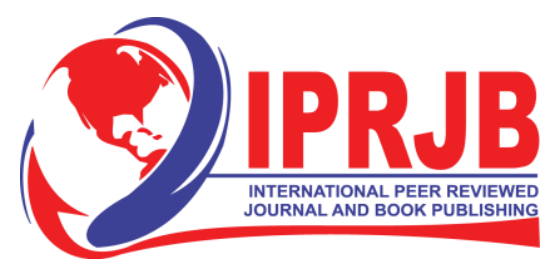

Www.iprjb.org

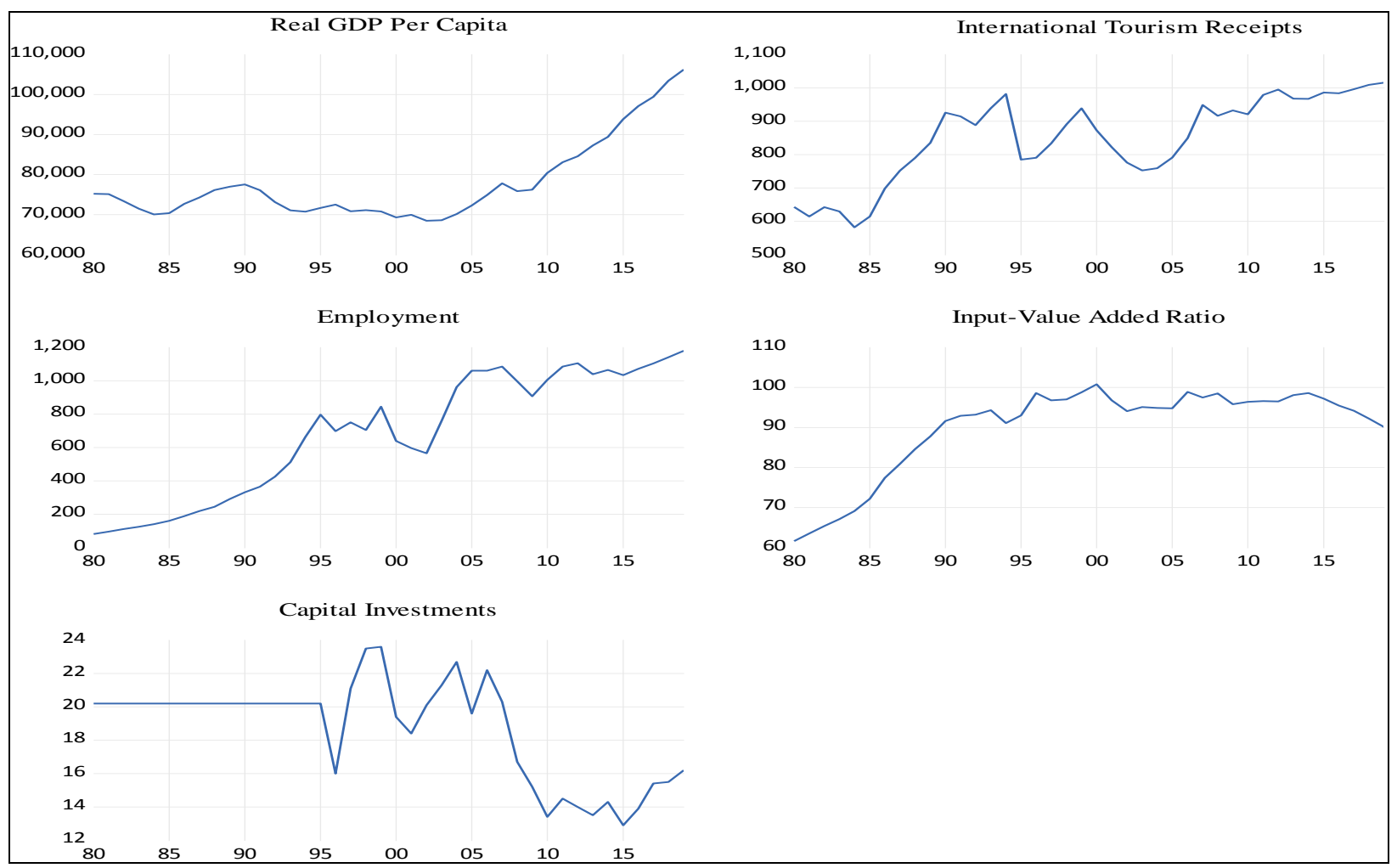

Figure 3: Descriptive Graphs

\subsection{Diagnostic Tests}

Diagnostic tests evaluate whether the estimation equation of the variables has any statistical error. It involves testing for serial correlation, heteroscedasticity and normality in the error term as well as testing for existence of stationarity, multi-collinearity and co-integration among the variables.

\subsubsection{Serial Correlation test}

Serial correlation occurs when the error term at a given time t correlates with the error term at another past time $t-i, i=1,2,3, \ldots$ Presence of serial correlation in a time series renders the estimates inefficient with underestimated standard errors and inflated t-statistics. In this study, Breusch-Godfrey Serial Correlation LM test is applied in which the null hypothesis that there is no serial correlation among the variables is tested. The null hypothesis is rejected when the Pvalue of the Chi-square statistic is more than $5 \%$.

In Table 3, the probability value of the Chi-square $(\mathrm{P}=0.0000)$ is less than $5 \%$. Thus, the null hypothesis that there is no serial correlation is not rejected. The variables in the equation are, therefore, not correlated.

\section{Table 3. Breusch-Godfrey Serial Correlation LM Test}

\begin{tabular}{llll}
\hline \hline F-statistic & 43.37224 & Prob. F(1,34) & 0.0000 \\
Obs*R-squared & 22.42264 & Prob. Chi-Square(1) & 0.0000 \\
\hline
\end{tabular}


International Journal of Economics

ISSN 2518-8437 (Online)

Vol.6, Issue 1, No.1. pp 1 - 22, 2021

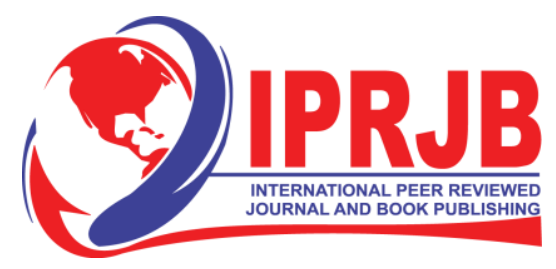

WwW.iprjb.org

\subsubsection{Heteroscedasticity test}

Heteroscedasticity occurs when the variance of the error term in each observation is different. This results in inefficient estimates and test statistics using the standard errors are not valid. The study used Breusch-Pagan-Godfrey test to test the null hypothesis of homoscedasticity and the results are presented in Table 4.

The probability value of the observed Chi-square is 0.26 per cent, which is lower than the $5 \%$ level of significance. Thus, the null hypothesis that the model is homoscedastic is not rejected.

Table 4. Breusch-Pagan-Godfrey test

\begin{tabular}{llll}
\hline F-statistic & 6.065964 & Prob. F(4,35) & 0.0008 \\
Obs*R-squared & 16.37683 & Prob. Chi-Square(4) & 0.0026 \\
Scaled explained SS & 15.95342 & Prob. Chi-Square(4) & 0.0031
\end{tabular}

\subsubsection{Normality test}

The test for normality was done by running the Jarque-Bera statistic test. The results in Figure 5 show that the residual of the estimation model is normally distributed, with a significant JarqueBera probability value of 40.7 per cent, greater than the 5 per cent level of significance.

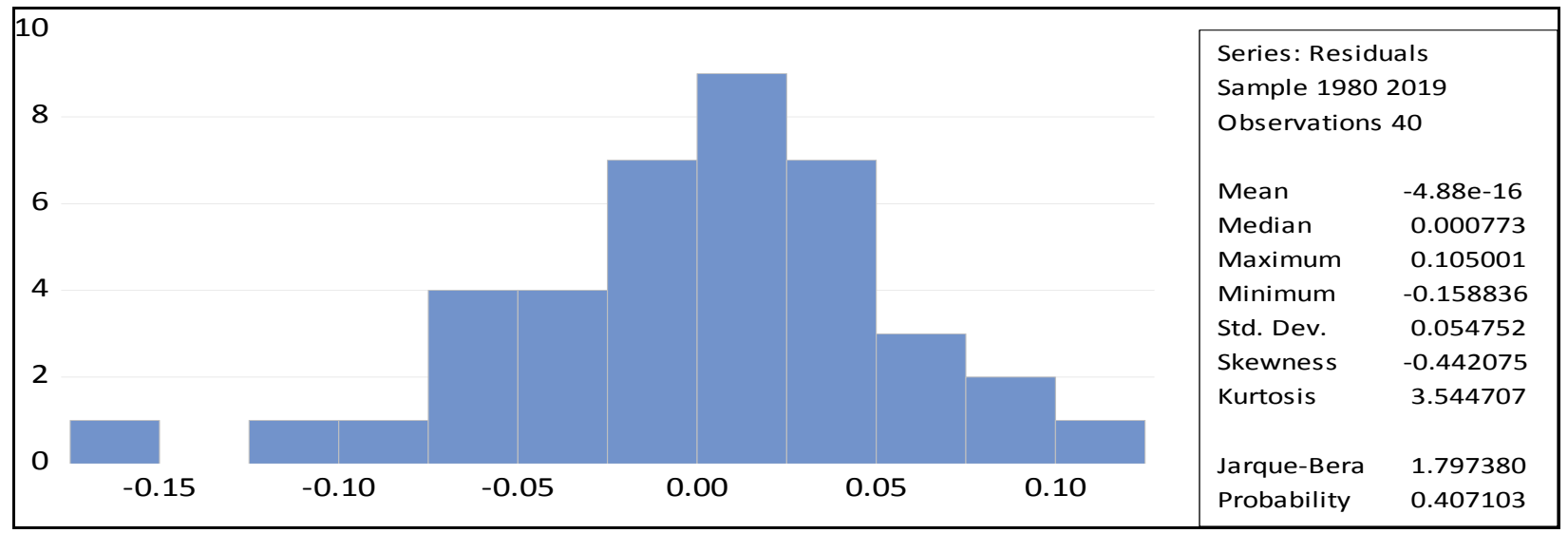

Figure 4: Normality Test Results

\subsubsection{Unit Root Test and Stationarity Test}

When analyzing time series data, it should be ensured that the series is stationary, meaning its mean and variance should be constant over time and the covariance between two periods should only depend on the distance between the two periods and not the actual time the value of the covariance was obtained, Gujarati (2011). Analysis of a non-stationary time series results in a spurious regression, a misleading result in which some of the variables will be associated with no causal relationships. Unit root test is used to examine stationarity in the time series. In this study, the unit root test was done using Augmented Dickey-Fuller(ADF) Unit Root Test, in which the null hypothesis that the time series is non-stationary is tested. The process involves comparing the resulting t-statistic with the critical t-value at $5 \%$ level of significance. The variable is stationary when the probability value, P-value, is less than 0.05 . From the results in Table 5 
International Journal of Economics

ISSN 2518-8437 (Online)

Vol.6, Issue 1, No.1.pp 1 - 22, 2021

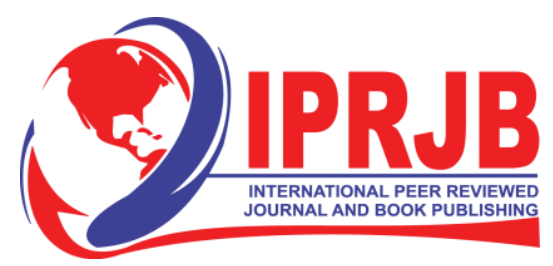

WwW.iprjb.org

tourism related employment and input-value added ratio are stationary at level while real GDP per capita, real international tourism receipts and tourism related capital investments are nonstationary at level. However, at first difference, all the variables are stationary at $5 \%$ level of significance.

Table 5: Augmented Dickey-Fuller Unit Root Test Results

\begin{tabular}{|c|c|c|c|c|c|c|c|}
\hline \multirow{2}{*}{ Variable } & \multirow[b]{2}{*}{$\begin{array}{l}\text { Critical } \\
\text { value }\end{array}$} & \multicolumn{2}{|c|}{ At level I(0) } & \multicolumn{2}{|c|}{ First Difference I(1) } & \multirow[b]{2}{*}{ P-value } & \multirow{2}{*}{ Resul } \\
\hline & & ${ }^{t}{ }^{t}$-statistic & P-value & $\begin{array}{l}\text { Critical } \\
\text { value }\end{array}$ & ${ }^{t}{ }$ t-statistic & & \\
\hline$\overline{\text { LGDP }}$ & -2.9412 & 0.6991 & 0.9906 & -2.9412 & -3.1174 & $0.0336^{*}$ & $\overline{\mathrm{I}(1)}$ \\
\hline LITR & -2.9390 & -1.5206 & 0.5128 & -2.9412 & -5.1538 & $0.0001^{*}$ & $\mathrm{I}(1)$ \\
\hline LEMPL & -2.9390 & -3.3391 & $0.0197 *$ & -2.9412 & -4.4533 & $0.0010^{*}$ & $\mathrm{I}(1)$ \\
\hline LIoR & -2.9390 & -4.4435 & $0.0010^{*}$ & -2.9412 & -3.7108 & $0.0078^{*}$ & $\mathrm{I}(1)$ \\
\hline LGFCF & -2.9390 & -1.7104 & 0.4183 & -2.9412 & -6.5575 & $0.0000^{*}$ & $\mathrm{I}(1)$ \\
\hline
\end{tabular}

Note: $*$ signifies the variable is stationary at $5 \%$ level of significance.

\subsubsection{Multi-Collinearity Test}

Multi-collinearity in multiple regression analysis occurs when there exists a linear relationship among the independent variables. When multi-collinearity exists in a model, the regression results will be skewed with more standard errors. This study used Variance Inflation Factors (VIF) to test for multi-collinearity. The VIF measures how much inflated the variance of the estimated coefficient of the regression if the independent variables are correlated. Multicollinearity is considered severe if the variance inflation factor(VIF) is greater than 10 . As indicated in Table 6, the centered VIF for each of the independent variables is less than 10, meaning international tourism receipts, tourism related employment, input-value added ratio and capital investments are not correlated.

Table 6. VIF Multi-Collinearity Test

\begin{tabular}{llll}
\hline \hline Variable & $\begin{array}{l}\text { Coefficient } \\
\text { Variance }\end{array}$ & $\begin{array}{l}\text { Uncentered } \\
\text { VIF }\end{array}$ & $\begin{array}{l}\text { Centered } \\
\text { VIF }\end{array}$ \\
\hline \hline LITR & 0.013681 & 7427.039 & 4.118283 \\
LEMPL & 0.001059 & 508.1705 & 8.217265 \\
LIOR & 0.038040 & 9195.951 & 8.424730 \\
LGFCF & 0.005008 & 510.6812 & 1.714792 \\
C & 0.590942 & 7076.283 & NA \\
\hline \hline
\end{tabular}

\subsubsection{Johansen Co-Integration Test}

Two or more-time series data are said to be co-integrated if there exists long term relationship, or equilibrium among them, Gujarati (2011). The various changes that occur in the economy over time could cause some long run relationship between real GDP per capita and tourism related variables like international tourism receipts, employment, input-value added ratio and capital investments. This long run relationship can be represented in a linear combination of the variables. From the stationarity tests, all the variables were found to be stationary at their first 
International Journal of Economics

ISSN 2518-8437 (Online)

Vol.6, Issue 1, No.1.pp 1 - 22, 2021

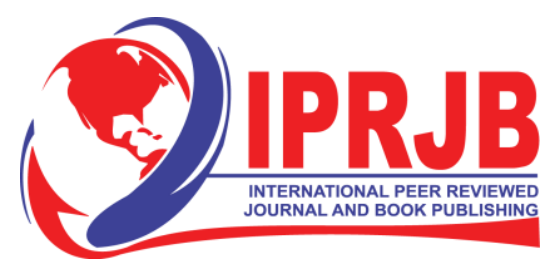

WwW.iprjb.org

difference, implying an integration of order 1, I (1). To ascertain existence of co-integration, this study employed Johansen co-integration approach in which two tests are carried out; Trace test and Maximum Eigen Value test. The Trace statistic and the Maximum Eigen statistic at 5\% level of significance is compared with the respective critical value for every number of co-integrating equations.

The Johansen co-integration test results are presented in Table 7. Both the Trace test and Maximum Eigen value test confirm presence of co-integration with at most 4 co-integrating equations. Thus, real GDP and international tourism receipts, employment, input-value added ratio and capital investments have a long-run relationship.

Table 7. Johansen Co-Integration Test Results

\begin{tabular}{|c|c|c|c|c|c|c|}
\hline \multirow{4}{*}{$\begin{array}{l}\text { Hypothesized } \\
\text { No. of CE(s) }\end{array}$} & \multicolumn{3}{|l|}{ Trace Test } & \multicolumn{3}{|c|}{ "Maximum Eigen Value Test } \\
\hline & Trace & 0.05 & & Max-Eigen & 0.05 & \\
\hline & & Critical & & & Critical & \\
\hline & Statistic & Value & Prob.** & Statistic & Value & Prob.** \\
\hline None * & 73.46419 & 69.81889 & 0.0248 & 36.13863 & 33.87687 & 0.0264 \\
\hline At most 1 & 37.32557 & 47.85613 & 0.3323 & 24.16910 & 27.58434 & 0.1289 \\
\hline At most 2 & 13.15647 & 29.79707 & 0.8843 & 8.170323 & 21.13162 & 0.8930 \\
\hline At most 3 & 4.986147 & 15.49471 & 0.8103 & 4.956655 & 14.26460 & 0.7473 \\
\hline At most 4 & 0.029492 & 3.841465 & 0.8636 & 0.029492 & 3.841465 & 0.8636 \\
\hline
\end{tabular}

Note: * denotes rejection of the hypothesis at the 0.05 level

\subsection{Regression Analysis}

Table 8 presents the coefficients of the long run relationship between real GDP and international tourism receipts, tourism related employment, input-value added ratio and capital investments. Equation 5 provides a summary of the regression of the variables.

LGDP $=0.6005$ LITR + 0.09701EMPL -1.0238LIoR - 0.2488LGFCF

The long term elasticities of real GDP per capita with real international tourism receipts, employment, tourism related economies of scale and capital investments are mixed as shown in Table 8. While real GDP per capita has a significant positive elasticity with international tourism receipts and tourism related employment, it presented a significant negative elasticity with tourism related capital investments and input-value added ratio. The goodness of fit in this regression is 78.4 per cent $\left(\mathrm{R}^{2}=0.7840\right)$, meaning that international tourism receipts, tourism related employment, economies of scale and capital investments account for $78.4 \%$ of the economic growth in the long run. 
International Journal of Economics

ISSN 2518-8437 (Online)

Vol.6, Issue 1, No.1.pp 1 - 22, 2021

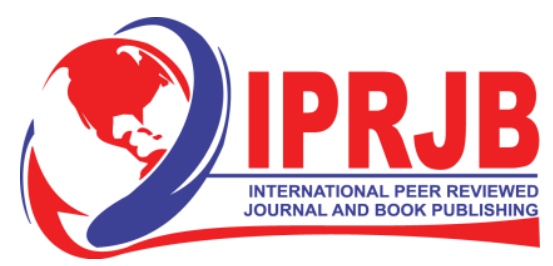

www.iprjb.org

Table 8. Long Run Regression Equation

\begin{tabular}{lllll}
\hline \hline Variable & Coefficient & Std. Error & t-Statistic & Prob. \\
\hline \hline LITR & 0.600524 & 0.116967 & 5.134118 & 0.0000 \\
LEMPL & 0.096951 & 0.032542 & 2.979241 & 0.0052 \\
LIOR & -1.023804 & 0.195038 & -5.249249 & 0.0000 \\
LGFCF & -0.248774 & 0.070765 & -3.515467 & 0.0012 \\
C & 11.92580 & 0.768728 & 15.51370 & 0.0000 \\
\hline \hline R-squared & 0.784007 & Mean dependent var & 11.25407 \\
Adjusted R-squared & 0.759323 & S.D. dependent var & 0.117810 \\
S.E. of regression & 0.057796 & Akaike info criterion & -2.747316 \\
Sum squared resid & 0.116914 & Schwarz criterion & -2.536206 \\
Log likelihood & 59.94633 & Hannan-Quinn criter. & -2.670986 \\
F-statistic & 31.76066 & Durbin-Watson stat & 0.586470 \\
Prob(F-statistic) & 0.000000 & & & \\
\hline \hline
\end{tabular}

\subsection{Vector Error Correction}

The insignificance of the relationship between real GDP per capita and tourism-related capital investments contradicts the theoretical production function that real output is a function of both labor and capital. The long run relationship equation therefore has a weakness. The weakness is corrected by running the vector error correction (VEC). The VEC examines the extent to which real GDP per capita adjusts to long run equilibrium and whether there's existence of short-run relationship between the real GDP per capita and the international tourism receipts, tourist related employment, input-value added ratio and capital investments.

The VEC results are shown in Table 9. The second column of the VECM results presents the cointegrating equation between real GDP per capita, international tourism receipts, employment, cost price-value added ratio and tourism related capital investments. As indicated in the table, the VECM results do not give the probability values (P-values), which are necessary in testing the hypotheses. 
International Journal of Economics

ISSN 2518-8437 (Online)

Vol.6, Issue 1, No.1. pp 1 - 22, 2021

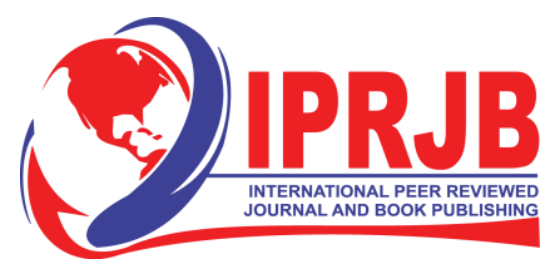

www.iprjb.org

Table 10. Estimated Model Coefficients

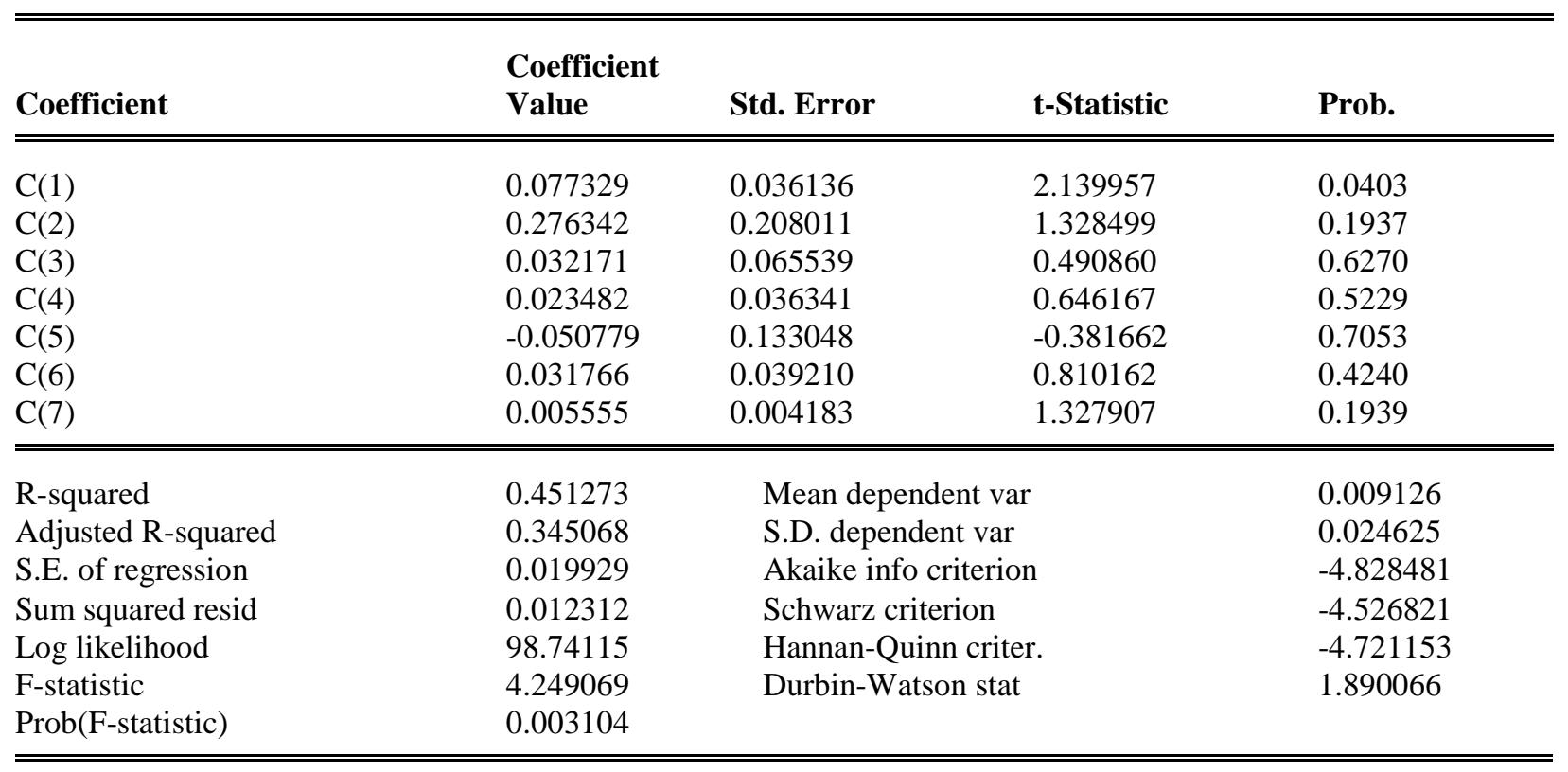

Examining short run relationship between the dependent variable and the independent variables entails testing the null hypotheses that there is no short run causality from international tourism receipts, tourism related employment, input-value added ratio and capital investments to real GDP per capita. In this case, $\mathrm{C}(3)=\mathrm{C}(4)=\mathrm{C}(5)=\mathrm{C}(6)=0$. Non- zero short run coefficients $\mathrm{C}(3), \mathrm{C}(4), \mathrm{C}(5)$ and $\mathrm{C}(6)$ will mean that international tourism receipts, employment, input-value added ratio and capital investments influence real GDP per capita in the short run. In this study, the Wald's test is used to test the null hypothesis that $\mathrm{C}(3)=\mathrm{C}(4)=\mathrm{C}(5)=\mathrm{C}(6)=0$. The significance of the resulting Chi-square statistic is determined using the probability values. The null hypothesis is rejected when the P-value is greater than $5 \%$.

The Wald's test results in Table 11 shows that each of the P-values is greater than 0.05 . Thus, the null hypothesis that there is no short run causality to real GDP per capita from international tourism receipts (ITR), tourism related employment (EMPL), economies of scale (IOR) and capital investments $(\mathrm{GFCF})$ is rejected. However, the F-statistic is significant $(\mathrm{P}=0.0031<0.05)$, explaining the low overall measure of model's goodness of fit, $\mathrm{R}^{2}=0.45$.

Table 11. Wald's Test Results

\begin{tabular}{lccc}
\hline \hline Relating Variables & Null hypothesis & Chi-square Statistic & P-value \\
\hline \hline ITR and GDP & $\mathrm{C}(3)=0$ & 0.240944 & 0.6235 \\
EMPL and GDP & $\mathrm{C}(4)=0$ & 0.417532 & 0.5182 \\
IOR and GDP & $\mathrm{C}(5)=0$ & 0.145666 & 0.7027 \\
GFCF and GDP & $\mathrm{C}(6)=0$ & 0.656362 & 0.4178 \\
\hline \hline
\end{tabular}


International Journal of Economics

ISSN 2518-8437 (Online)

Vol.6, Issue 1, No.1.pp 1 - 22, 2021

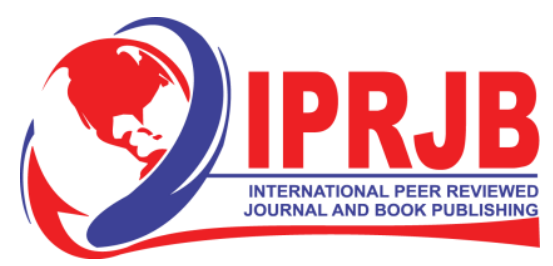

WWW.iprjb.org

\subsection{Granger Causality Test}

Granger causality is a statistical process that examines whether one-time series can be used to forecast another time series. Although regression reflects correlations in ordinary sense, Granger (1969) argue that causality is tested by measuring the ability of past values of a time series to predict future values of another time series. In this study, the Granger causality is examined by testing the significance of the F-statistic. The null hypothesis is rejected if the probability value of the F- statistic is greater than $5 \%$.

As shown in Table 12, the probability values of each of the F statistics in the Granger causality test is greater than 0.05 , implying that international tourism receipts, tourism related employment, economies of scale and capital investments, all granger cause real GDP per capita. Thus, all the considered aspects of international tourism stimulate growth of the economy in Kenya. This supports the causality relationship outcomes from the Wald's test.

Table 12. Granger Causality Test Results

\begin{tabular}{|c|c|c|c|}
\hline Null Hypothesis: & Obs & F-Statistic & Prob. \\
\hline LITR does not Granger Cause LGDP & 39 & 0.00334 & 0.9542 \\
\hline LGDP does not Granger Cause LITR & & 1.45621 & 0.2354 \\
\hline LEMPL does not Granger Cause LGDP & 39 & 4.06394 & 0.0513 \\
\hline LGDP does not Granger Cause LEMPL & & 0.05591 & 0.8144 \\
\hline LIOR does not Granger Cause LGDP & 39 & 1.31276 & 0.2595 \\
\hline LGDP does not Granger Cause LIOR & & 3.15260 & 0.0843 \\
\hline LGFCF does not Granger Cause LGDP & 39 & 2.56262 & 0.1182 \\
\hline LGDP does not Granger Cause LGFCF & & 1.02899 & 0.3172 \\
\hline LEMPL does not Granger Cause LITR & 39 & 2.12007 & 0.1540 \\
\hline LITR does not Granger Cause LEMPL & & 0.14761 & 0.7031 \\
\hline LIOR does not Granger Cause LITR & 39 & 3.62561 & 0.0649 \\
\hline LITR does not Granger Cause LIOR & & 2.16186 & 0.1502 \\
\hline LGFCF does not Granger Cause LITR & 39 & 0.41067 & 0.5257 \\
\hline LITR does not Granger Cause LGFCF & & 2.90918 & 0.0967 \\
\hline LIOR does not Granger Cause LEMPL & 39 & 0.81901 & 0.3715 \\
\hline LEMPL does not Granger Cause LIOR & & 0.47348 & 0.4958 \\
\hline LGFCF does not Granger Cause LEMPL & 39 & 0.00028 & 0.9866 \\
\hline LEMPL does not Granger Cause LGFCF & & 2.18700 & 0.1479 \\
\hline LGFCF does not Granger Cause LIOR & 39 & 3.33812 & 0.0760 \\
\hline LIOR does not Granger Cause LGFCF & & 0.63826 & 0.4296 \\
\hline
\end{tabular}

\subsection{Statistical Analysis}

This statistical analysis presents a breakdown of the regression and causality results into specific study objectives. 


\subsubsection{Tourism receipts and Economic Growth}

When tourists visit a country, they consume variety of goods and services. The host country derives income from these expenditures. This income has been measured in this study using international tourism receipts. The results in this study showed that international tourism receipts positively influence real GDP in both short run and long run. From the long run relationship in equation 5 , a $1 \%$ increase in international tourism receipts causes a significant increase in real GDP per capita by $0.6 \%$. Similarly, VECM analysis presented in Table 4.9 shows that a $0.03 \%$ increase in real GDP per capita in the short run is derived when international tourism receipts are increased by $1 \%$. These findings are in line with Tabash (2017) that found existence of a long run relationship between international tourism receipts and economic growth in the State of Palestine. Similarly, the study by Eeckels et al. (2012) in Greece on the relationship between cyclical components of international tourism and those of economic supported the findings in this study when it found that cyclical components of international tourism receipts caused cyclical components of real GDP. The Granger causality test results in Table 4.11 found a bidirectional causality in which international tourism receipts and real GDP per capita were found to Granger cause each other. Thus, expanding the growth of the economy leads to increased international tourism receipts, and higher receipts from international tourism causes increased real GDP per capita.

\subsubsection{Employment and Economic Growth}

Employment is measured by the number of jobs created by tourism industries such as hotels and food services, transport and information communication, arts and entertainment, wholesale and retail trade, travel agencies and tour guides among others that produce tourism products and services. The influence of tourism related employment on real GDP per capita was found to be positively significant in the long run $(\mathrm{p}=0.5 \%)$. A $1 \%$ increase in tourism related employment was found to cause an estimated $0.1 \%$ increase in the level of real GDP per capita. This relationship between tourism related employment and economic growth corroborates with Thuku et al. (2019) who examined employment elasticities to growth of priority sectors of the economy in Kenya and found out that elasticities among the priority sectors, especially the service sectors, had relatively higher employment elasticities to growths in the long run. In the short run however, jobs created by tourism related industries were found to positively influence real GDP per capita as shown in Table 4.9, causing a $0.02 \%$ increase for every $1 \%$ increase of the jobs created. In Table 4.11, the hypothesis that employment does not granger cause real GDP per capita is rejected. This confirms the results from both long run and short run regression. The Granger causality test presented a bi-directional causality between tourism related employment and real GDP per capita. A similar study by Seyfried (2011) on ten largest states in the US found that economic growth had an immediate impact on employment, with the effects felt in several quarters after.

\subsubsection{Economies of Scale and Economic Growth}

When output of industries increase faster than the total cost of inputs, the industries are expected to realize economies of scale. These economies of scale are derived either when the price of inputs decrease or when a better production technology is adopted. In this study, these economies of scale are measured using input-value added ratios of the tourism industries. The economies of scale are said to be increasing when the ratio continuously decline, implying the cost of inputs 
constantly reduce with increasing output. In the estimated long run relationship results in Table 4.7 , a $1 \%$ decline in input-value added ratio was found to cause a $1.02 \%$ increase in real GDP per capita in the long run, while the vector error correction analysis revealed that when the inputvalue added ratio decline by $1 \%$, real GDP per capita increased significantly by $0.05 \%$ in the short run.

When Cabrera et al (2006) studied performance of European airline industry, they found a similar result with this study, establishing that growth of the airline industry resulted from mergers and alliances that reduced the cost structures while increasing the output. A similar finding was reported by Wang and Weng (2004) when they found that activities of accommodation, food and beverage in Taiwan's international tourist hotels realized economies of scale when they are provided together. This increases the valued added of these industries, resulting in increased real GDP per capita. The Granger causality analysis in this study presented a bi-directional causality between tourism related economies of scale and real GDP per capita.

\subsubsection{Capital Investments and Economic Growth}

Capital goods are used for further production of goods and services. The findings in this study have shown that capital investments negatively influenced growth of real GDP per capita. From the findings in Table 12 and Equation 3, a 1\% increase in capital investments caused a significant decline in real GDP per capita by $0.25 \%$ in long run. However, a similar $1 \%$ increase in capital investments caused a $0.03 \%$ increase in real GDP per capita in the short run. The short run regression results agree with Akindele (2016) study findings that found capital formation to have a positive relationship with economic growth in Nigeria. Similarly, the findings in Table 4.9 showed a bi-directional causality between tourism related capital investments and real GDP per capita, corroborating the findings by Uneze (2013) that higher capital formations in SubSaharan African countries caused growth in real GDP, and higher levels of real GDP led to accumulation of more capital.

\subsection{CONCLUSIONS AND RECOMMENDATIONS}

\section{Conclusion}

The study concluded that international tourism plays a significant role in increasing the levels of economy in Kenya. The international tourism receipts, and economies of scale derived by tourism industries contribute to increased overall output and real GDP per capita. When more fixed capital is accumulated, it increases productive capacity of both physical capital and labor. The bi-directional causality obtained in this study imply that when international tourism expands, the country realizes increased economic growth and vice versa. Therefore, when international tourists visit the country, they consume the various tourism products produced in the country, increasing receipts in many tourism-related industries such as hotels and food services, wholesale and retail trade, transport and information communication, entertainment, arts and recreation and travel agencies, tour guides among others. The receipts derived by these industries are used to expand production of goods and services, resulting in more capital investments and creation of more job opportunities. These increased tourism-related output and competition among the producers of tourism products result in production of quality products, causing increased efficiency and economies of scale that also lead to increase in the value added in these 
International Journal of Economics

ISSN 2518-8437 (Online)

Vol.6, Issue 1, No.1. pp 1 - 22, 2021

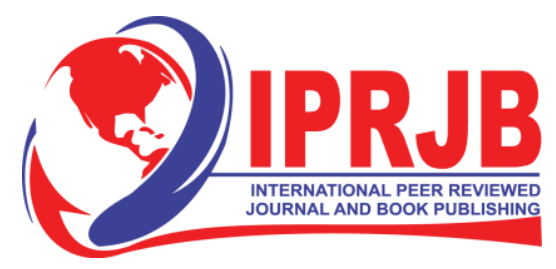

WwW.iprjb.org

tourism activities. It's therefore concluded that tourism-led growth hypothesis indeed works in Kenyan economy.

\section{Recommendations}

The country should enact policies that promote tourism related activities because the benefits derived from tourist expenditures positively influence the growth of the economy. Institutions such as Brand Kenya, Tourism Promotion Council, the Ministry of Tourism and recruitment of international tourism ambassadors should be strengthened to ensure more foreign tourists are attracted into the country. The study also recommends that there is need for more and well trained manpower to provide internationally competitive services. Hotels will require well trained managers, waiters, taxi services will need professional drivers and visitors will need very knowledgeable and educated tour guides. To achieve this, the government and private sector should enhance the training of personnel to serve in the tourism and tourism related industries. The study also recommends that government should adopt policies that both lower production cost of tourism related products as well as discouraging foreign competition in the domestic market. This will create ready market for domestic production as well as lowering production costs that are associated with imports. The study also recommended that the government should consider investing in infrastructure such as roads, railways and airports as well as provide utilities like water, electricity and sewer services in tourist destination areas such as Lamu, Kwale, Naivasha, Nanyuki, Kisumu, Baringo and others.

\section{REFERENCES}

Ahmad, J., \& Kwan, A. (1991). Causality Between Exports and Economic Growth: Empirical evidence from Africa. Economic Letters, 37(3).

Bhagwati, J., \& Srinivasan, T. (2002). Trade and Poverty in the Poor Countries. American Economic Review, 92.

Chao, A., Chazdon, R. L., Colwell, R. K., \& Shen, T.-J. (2006). Abundance-Based Similarity Indices and Their Estimation When There Are Unseen Species in Samples. Biometrics, $62(2)$.

Chou, M. (2013). Does tourism development promote economic growth in transition countries? A panel data analysis. Economic Modelling.

Clancy, M. (1999). Tourism and Developemnt-Evidence from Mexico. Annals of Tourism Research, 26.

Hatemi-J, A., \& Gunduz, L. (2005, February). Is the Tourism-led Growth Hypothesis Valid for Turkey? Applied Economics Letters, 12(8).

Holzner, M. (2011, August). Tourism and Economic Development: The Beach Disease? Tourism Management, 32(4).

Mathieson, A., \& Wall, G. (1982). Tourism: Economic, physical, and social impacts. Scientific Research. 
